\title{
ACCESS TO JUSTICE FOR CONSUMERS IN TURKEY: THE NEED FOR ENHANCING CONSUMER DISPUTE RESOLUTION THROUGH ONLINE DISPUTE RESOLUTION
}

\author{
Serkan KAYA*
}

\begin{abstract}
In recent years, consumer spending has dominated the Gross Domestic Product (GDP). The continuously increasing consumer spending boosts the possibility of consumer disputes. In Turkey, there is still a need for enhanced consumer redress, although there is a continuing attempt to bring Turkish consumer law into line with the European Union (EU) legislation to meet the needs of our digitised society. This paper explores the powers and deficiencies of the Turkish Consumer Redress System and examines the judicial process to the implementation of consumer access to justice. This article evaluates the resolution of consumer disputes and analyses the EU ODR regime and best practices seeking for models to be followed by Turkey. The research of ODR and its applicability in consumer disputes proposes assembling instructions for outlining a new legal framework and establishing an effective ODR platform for resolving consumer disputes in Turkey.
\end{abstract}

Key words: Access to Justice, Alternative Dispute Resolution, Consumer Disputes, Consumer Rights, Online Dispute Resolution

\section{TÜRKIYE'DE TÜKETİCILER İÇIN ADALETE ERISSIM: ONLINE UYUŞMAZLIK ÇÖZÜMÜ YOLUYLA TÜKETİCI UYUŞMAZLIKLARININ ÇÖZÜMÜNÜ GELIŞTIRME İHTIYACI}

\section{$\ddot{O} Z$}

Son yıllarda, tüketici harcamaları Gayri Safi Yurtiçi Hasıla (GSYH) içindeki en yüksek paya sahip olmaya başladı. Sürekli artan tüketici harcamaları, tüketici anlaşmazlıklarının ortaya çıkma olasılı̆̆ını da artırmıştır. Türkiye)de dijitalleşmiş toplumumuzun gereksinimlerini karşılamak için Türk tüketici hukukunu Avrupa Birliğ̈i (AB) mevzuatı ile uyumlu hale getirmek için sürekli bir girişimde bulunulmuştur, ancak yine de gelişmiş tüketici haklarının korunmasına daha fazla ihtiyaç vardır. Bu makale,

* Dr. Lecturer, Istanbul Medeniyet University, Law Faculty, Department of Civil Procedure, Enforcement and Bankruptcy Law / ISTANBUL e-mail: serkan.kaya@medeniyet.edu.tr ORCID: 0000-0003-2507-3372

DOI : : 10.34246/ahbvuhfd.1066655

Yayın Kuruluna Ulaştığı Tarih : 04/09/2021

Yayınlanmasının Uygun Görüldüğ̈̈ Tarih: 22/11/2021 
Türk Tüketici Hukuk Sistemi'nin güçlü ve zaylf yönlerini tartı̧makta ve tüketicinin adalete erişiminin uygulanmasına yönelik hukuki yaklaşımı sorgulamaktadır. Bu makale, tüketici uyuşmazllklarının çözümünü değerlendirmekte ve Türkiye tarafindan ögrrenilecek dersleri bulmak için AB tüketici çevrimiçi uyuşmazlık çözümü (ODR) rejimini analiz etmektedir. Çevrimiçi uyuşmazlık çözümünün ve bunun tüketici uyuşmazlıklarındaki uygulamasının ele alındlğı bu çalışma, Türkiye'deki tüketici uyuşmazlıklarının çözümü için yeni bir yasal çerçeve tasarlamaya ve verimli bir ODR platformu oluşturmaya yönelik tavsiyelerde bulunmayı amaçlamaktadır.

Anahtar Kelimeler: Adalete Erişim, Alternatif Uyuşmazlık Çözümü, Tüketici Uyuşmazlıkları, Tüketici Hakları, Çevrimiçi Uyuşmazlık Çözümü

\section{Introduction}

In Turkey, courts are still considered as the main dispute resolution forum for civil disputes. Evidence of this is the exorbitant number of pending cases (over 3 million cases), which take an unreasonable time (for commercial disputes is around 547 days, for labour disputes is 555 days) to reach a final judgement ${ }^{1}$. Regarding consumer disputes, the average duration of a case in a consumer court is 425 days $^{2}$. According to the recent report published by the Directorate General of Consumer Protection and Market Surveillance, 547,207 complaints were submitted to the Consumer Arbitration Boards in $2019^{3}$. In 2019, 55.219 consumer complaints were also submitted to the Directorate General of Consumer Protection and Market Surveillance ${ }^{4}$. Moreover, the Ministry of Trade received 371.601 calls via dialling 175 concerning consumer complaints in $2019^{5}$.

1 Republic of Turkey Ministry of Justice Statistics (2019), <https://adlisicil.adalet.gov.tr/Resimler/SayfaDokuman/1062020170359HizmeteOzel-2019-bask1-İSA.pdf $>$ Date of Access 20 March 2021.

2 Republic of Turkey Ministry of Justice Statistics (2019), $<$ https://adlisicil.adalet.gov.tr/Resimler/SayfaDokuman/1062020170359HizmeteOzel-2019-bask1-ISA.pdf $>$ Date of Access 20 March 2021.

3 Republic of Turkey Ministry of Trade Statistics (2020), <https://tuketici.ticaret.gov.tr/yayinlar/istatistikler> Date of Access 5 April 2021.

4 Republic of Turkey Ministry of Trade Statistics (2020), <https://tuketici.ticaret.gov.tr/yayinlar/istatistikler> Date of Access 5 April 2021.

5 Republic of Turkey Ministry of Trade Statistics (2020), <https://tuketici.ticaret.gov.tr/yayinlar/istatistikler> Date of Access 5 April 2021. 
To date, many procedural reforms have been adopted and the consumer redress system has improved. For example, consumer arbitration boards, an out-of-court system, are authorised to resolve disputes, which do not exceed 11.330 Turkish Lira, within a period of six months. Recently, on July 28, 2020, the Law Amending the Civil Procedure Law and Certain Laws numbered 7251 added "Article 73/A", "Mediation as a prerequisite," to the Consumer Protection Law Numbered 6502 which states that going to mediation is a prerequisite to file lawsuits for consumer disputes involving TRY 11,330 and above monetary claims ${ }^{6}$. However, the existing mechanisms that include the consumer arbitration boards and the consumer courts are not effective in resolving the huge number of consumer disputes arising from online transactions; thus, in order to enhance consumers' access to justice modern, fast, less formal and cost-effective mechanisms supported by ICT are undoubtedly needed in Turkey.

Developed regions, such as the US and the EU, have long established Online Dispute Resolution (ODR) systems and currently have advanced systems in place to handle disputes arising in many different fields ${ }^{7}$. Emerging countries, such as Turkey, are several steps back in the area of ODR, not taking full advantage of the developments in information communication technology (ICT). This article evaluates the resolution of consumer disputes in the digital age and analyses the EU ODR regime and best practices seeking for models to be followed by Turkey. The research of ODR and its applicability in consumer disputes proposes assembling instructions for outlining a new legal framework and establishing an effective ODR platform for resolving consumer disputes in Turkey. Such a framework will hopefully contribute to increasing consumers' access to justice, which will improve the level of trust and confidence of millions of consumers in Turkey.

\section{The Popularity and the Need for Modernisation of ADR}

ADR can be considered to be an essential method in dispute resolution, a structured process with a third-party intervention (in mediation and arbitra-

6 This monetary threshold is determined and announced each year in the Official Gazette by the Ministry of Trade. See CPL Article 68, and the Regulation on Consumer Arbitration Board Article 6.

7 Mohamed S. Abdel Wahab, Ethan Katsh and Daniel Rainey, ODR: Theory and practice, 2nd edn, Eleven International, 2021; Jie Zheng, Online Resolution of E-commerce Disputes: Perspectives from the European Union, the UK, and China. Springer, 2020; Pablo Cortés, The law of consumer redress in an evolving digital market: Upgrading from Alternative to Online Dispute Resolution, Cambridge University Press, 2018. 
tion but not in negotiation) and avoidance of traditional litigation. Parties can use ADR methods, which usually provide effective, adjustable, confidential and less costly solutions, in comparison to court litigation, to avoid lengthy court proceedings for transnational disputes concerned with conflicts of jurisdiction and determination of law ${ }^{8}$. International laws have been developed in a way to harmonise international ADR applications, such as the New York Convention", and the UNCITRAL Model Law on International Commercial Arbitration $1985^{10}$.

While ADR provides significant advantages for parties compared to court litigation, parties may face difficulties, such as travelling and having face to face (F2F) meeting for resolving disputes by using ADR systems ${ }^{11}$. With the development of ICT and the growth of digitalised economies, traditional ADR systems may be left behind to some extent because of the limits of the jurisdiction and the various prohibitive costs of legal proceedings in particular jurisdiction, such as the challenge of the determination of the place of business. Therefore, for meeting the legal, economic and social requirement of the globalised world, particularly in response to the COVID-19 crisis $^{12}$, there is a need for modernisation of ADR to provide a cost-effective, but more practical solution to resolve e-commerce disputes ${ }^{13}$.

8 Terence Lau and Lisa Johnson, The Legal and Ethical Environment of Business, Saylor Foundation, 2011, p.109.

9 United Nations Convention on the Recognition and Enforcement of Foreign Arbitral Awards, New York, 10 June 1958 (The New York Convention 1958), <https://uncitral.un.org/en/texts/arbitration/conventions/foreign_arbitral_awards/status2 $>$ Date of Access 30 Mart 2021

10 UNCITRAL Model Law on International Commercial Arbitration 1985, <https://uncitral. un.org/sites/uncitral.un.org/files/media-documents/uncitral/en/06-54671_ebook.pdf> Date of Access 5 Nisan 2021.

11 Pablo Cortés, Online Dispute Resolution for Consumers in the EU, Routledge, 2011; Ethan Katsh and Janet Rifkin, Online Dispute Resolution: Resolving Conflicts in Cyberspace, Jossey-Bass, 2001; Gabrielle Kaufmann-Kohler and Thomas Schultz, Online Dispute Resolution, Kluwer Law International, 2004; Julia Hörnle, Cross-border Internet Dispute Resolution, Cambridge University Press, 2009; Mohamed Abdel Wahab, Ethan Katsh, and Daniel Rainey, Online Dispute Resolution: Theory and Practice, $2^{\text {nd }} \mathrm{edn}$, Eleven International, 2021; Faye Fangfei Wang, Online Arbitration, Informa Law from Routledge, 2017; Melis Ercan, Uyuşmazlıkların Online Çözüm Yöntemleri, LLM Thesis, 2012.

12 Seda Özmumcu, "Dünyada ve Ülkemizde Online Uyuşmazlık Çözümleri Bağlamında Online Tahkim ve Uygulamaları", 2020, 78 (2) İstanbul Hukuk Mecmuası, p. 431.

13 Pablo Cortes, The Law of Consumer Redress in An Evolving Digital Market: Upgrading from Alternative to Online Dispute Resolution, Cambridge University Press, 2018, p. 43. 


\section{Online Dispute Resolution}

In order to create a fast, cost-effective, simple and more efficient resolution system for disputes, the modernisation of ADR started through an ODR pilot project entitled 'Virtual Magistrate' at Villanova University in $1996^{14}$. Due to the failure of this project, this ODR system was not considered to be very beneficial. However, day after day, the notion of ODR has been strengthened and used by well-established and non-profit organisations, such as the American Bar Association (ABA), the American Arbitration Association (AAA) and the World Intellectual Property Organisation (WIPO).

Even though ODR (otherwise called 'e-ADR', 'online ADR' and 'Internet Dispute Resolution') has been used in developed countries in the EU and the US, discussed by many scholars since the $1990 \mathrm{~s}^{15}$. The definitions of ODR already used in the literature is an obstacle for having a more precise and broadly accepted definition of ODR. For example, Kaufman- Kohler and Schultz state three evaluations, namely cyberspace, non-adjudicative ADR and arbitration $^{16}$. These authors also recognise that the main feature of a viable definition of ODR is that it focuses on the problems posed by the online-operated inclusive feature ${ }^{17}$. The ABA Task Force on E-Commerce and ADR defines ODR as follows:

"ODR is a broad term that encompasses many forms of ADR and court proceedings that incorporate the use of the internet, websites, email communications, streaming media and other information technology as part of the dispute resolution process. Parties may never meet face to face when participating in ODR. Rather, they might communicate solely online." 18

As described by the ABA Task Force, ODR is not only a combination of ADR with ICT, but also includes court proceedings (even it is not an ADR

14 Faye Fangfei Wang, Online Arbitration, Informa Law from Routledge, 2017, p. 6.

15 Pablo Cortés and Arno R. Lodder, “Consumer Dispute Resolution Goes Online: Reflections on the Evolution of European Law for Out-Of-Court Redress", 2014, 21 (1), Maastricht Journal, p.13, 14.

16 Gabrielle Kaufmann-Kohler and Thomas Schultz, Online Dispute Resolution: Challenges for Contemporary Justice, Kluwer Law International, 2004, p.7.

17 ibid

18 American Bar Association Task Force on E-Commerce and ADR Executive Summary of Final Recommendations, Final Report August 2002, 1. 
method) and $\mathrm{ICT}^{19}$.

The recent definition of ODR was declared by the UNCITRAL in the Technical Notes on ODR 2016. Article 24 stipulates that "ODR is a mechanism for resolving disputes facilitated through the use of electronic communications and other ICT"20. In the digital age, with the development of technology and impact of Covid-19 on proceedings of legal systems, ICT has been rapidly combined with methods of traditional litigation and ADR. The appearance of ODR has expanded with the development of dispute resolution technologies. This technology has been characterised as the 'fourth party" ${ }^{21}$.

\section{A. The Most Common Forms of ODR}

ODR, in its broader sense, may involve several methods. It basically includes any extrajudicial mechanisms that settle disputes by the use of ICT and especially the internet. Recently, four most frequently used methods of ODR systems are namely online negotiation, online mediation, online arbitration and online mediation-arbitration (med-arb). They shall be briefly discussed below.

Online Negotiation: The main principle of negotiation is that no third party is involved in communication between two or more people when they attempt to reach an agreement ${ }^{22}$. In other word, disputed parties seek to reach an agreement without impartial body assistance or supervision ${ }^{23}$. The use of ICT tools and software has increased the possibility of resolution of disputes through negotiation. With the help of online negotiation (also called 'e-negotiation' or 'cyber negotiation'), courtrooms and law firms move online, result-

19 Serkan Kaya, Consumer Dispute Resolution in the Digital Age: Online Dispute Resolution, Oniki levha, 2020, p. 15.

20 UNCITRAL Technical Notes on ODR, Article 24, <https://www.uncitral.org/pdf/english/ texts/odr/V1700382_English_Technical_Notes_on_ODR.pdf $>$ Date of Access 5 January 2021.

21 Ethan Katsh and Janet Rifkin, Online Dispute Resolution: Resolving Conflicts in Cyberspace, Jossey-Bass, 2001, p. 93.

22 Arno R Lodder and John Zeleznikow, Enhanced Dispute Resolution Through the Use of Information Technology, Cambridge University Press, 2010, p.2; Julio César Betancourt and Elina Zlatanska, "Online Dispute Resolution (ODR): What Is It, And Is It the Way Forward?”, 2013, 79, International Journal of Arbitration, Mediation and Dispute Management, p. 259.

23 Colin Rule, Online Dispute Resolution for Business, Jossey-Bass, 2002, p. 38. 
ing in the development of the thought of electronic-based e-negotiations ${ }^{24}$.

Online Mediation: Online mediation (also called 'e- mediation' or 'cyber mediation') is web-based, as opposed to a 'F2F based', mechanism ${ }^{25}$. One of the essential differences between traditional mediation and online mediation is that the parties and the mediator communicate via the internet, usually over sophisticated communication platforms ${ }^{26}$. The e-mediation method follows a standard route or a set of stages typically subjected to deadlines, recording of events, flow processes and complicated schemes with computerised algorithms that assist in optimising offers ${ }^{27}$.

Online Arbitration: Online arbitration (also called e-arbitration, electronic arbitration, cyber-arbitration and virtual arbitration) is often referred to as an online version of traditional arbitration ${ }^{28}$. Online arbitration commences with a valid online arbitration agreement and is concluded with a final online arbitral award ${ }^{29}$. In online arbitration, the disputants, the arbitral tribunal, experts and related parties are supposed to make use of electronic devices, including sophisticated software and hardware devices, to participate in the online proceedings ${ }^{30}$.

Online Med-Arb: Due to the shortcomings of online arbitration and online mediation, mixed methods combining online mediation and online arbitration has emerged as forms of ODR in recent years. In the online med-arb ${ }^{31}$,

24 Betancourt and Zlatanska, p. 259.

25 Seda Özmumcu, "Online Uyuşmazlık Çözümleri ve Online Arabuluculuk "Dijital Adalet Mümkün Mü?” Sistem Üzerine Bazı Değerlendirmeler”, 2020, Prof. Dr. Türkan Rado’nun Anisina Armă̆an, p. 365-420.

26 Joel B. Eisen, “Are We Ready for Mediation in Cyberspace?”, 1998, Brigham Young University Law Review, p. 1305-1358; Sarah Rudolph Cole and Kristen M. Blankley, "Online Mediation: Where We Have Been, Where We Are Now, and Where We Should Be", 2006, 38 U. Tol. L. Rev. p. 193; Faye Fangfei Wang, Online Dispute Resolution, Chandos, 2009, p. 32.

27 Kaya, 17.

28 Armağan Ebru Bozkurt Yüksel, “Online International Arbitration”, 2007, 4 (1), Ankara Law Review, p. 86.

29 Betancourt and Zlatanska, p. 262.

30 Dusty Bates Farned, “A New Automated Class of Online Dispute Resolution: Changing the Meaning of Computer-Mediated Communication", 2011, 2, Faulkner Law Review, p. 335.

31 For more detail about online med-arb see: Dafna Lavi, "Three Is Not a Crowd: Online Mediation-Arbitration in Business to Consumer Internet Disputes", 2016, 37, University of 
which combines online arbitration and online mediation, the dispute is primarily tried to be resolved through online mediation, in the event that mediation fails, the dispute is resolved through online arbitration.

\section{B. International Regulatory Development of ODR}

In the digitalised era, due to legal, social, political, technical, economic and cultural differences, it has been difficult to introduce an ODR system. When considering the diversity in the countries' legal systems, judicial complexity has been an obstacle for the establishment of an international treaty-based ODR system ${ }^{32}$. The recent UNCITRAL Model Law on International Commercial Mediation and International Settlement Agreements Resulting from Mediation 2018 ${ }^{33}$, existing the New York Convention, the UNCITRAL Model Law on International Commercial Arbitration, the UN Convention on the Use of Electronic Communications in International Contracts ${ }^{34}$ and the UNCITRAL Arbitration Rules ${ }^{35}$ do not present any special commands concerning ODR, but offer some useful guidance for dealing with international disputes via ODR methods. Since the beginning of the new millennium, scholars have emphasised the need for international co-operation and agreements on harmonised ODR rules ${ }^{36}$.

In 2010, in its 43rd session the UNCITRAL decided to establish a working group, the Working Group III, due to the need for an effective dispute resolution and for a set of general principles in the field of e-commerce ${ }^{37}$. The initial aim of the working group was to establish detailed rules on the use of

Pennsylvania Journal of International Law, p. 871.

32 American Bar Association's Task Force on Electronic Commerce and Alternative Dispute Resolution in Cooperation with the Shidler Centre for Law, Commerce and Technology, University of Washington School of Law, "Addressing Disputes in Electronic Commerce: Final Recommendations and Report", 2002, 58, Business Lawyer, p. 415, 450.

33 UNCITRAL Model Law on International Commercial Mediation and International Settlement Agreements Resulting from Mediation, 2018 (amending the UNCITRAL Model Law on International Commercial Conciliation, 2002).

34 United Nations Convention on the Use of Electronic Communications in International Contracts (New York, 2005).

35 UNCITRAL Arbitration Rules (with new Article 1, para. 4, as adopted in 2013); UNCITRAL Arbitration Rules (as revised in 2010); and UNCITRAL Arbitration Rules (1976).

36 Faye Fangfei Wang, Online Arbitration, Informa Law from Routledge, 2017, p. 43.

37 United Nations Commission on International Trade Law, 44th session, 'Report of Working Group III (Online Dispute Resolution) on the work of its twenty-second session', A/ CN.9/716 ,27 June-15 July 2011. 
ODR to resolve disputes arising in e-commerce ${ }^{38}$. There is not yet any international legislation on ODR for resolving cross-border consumer disputes and this is why the UNCITRAL requested a study setting out the basic rules about ODR. More specifically, the Working Group III was concerned with the use of ODR in resolving cross-border disputes arising from e-commerce and the preparation of detailed rules of procedure related to ODR. It is worth noting that the Working Group III focused not only on ODR for B2C disputes but also for B2B disputes. The Working Group III started its activities in order to create international legislation. The Working Group envisioned a three-stage ODR plan, which would start with negotiations between the participants and, if parties do not reach an agreement through negotiation, parties would go to mediation. The last stage would require arbitration ${ }^{39}$. However, the Working Group encountered problems and struggled to achieve its mandate. These difficulties occurred in the context of the binding arbitration award, which was the last step in the stages of the specially designed ODR procedure, and ultimately changed the direction of the work of the Working Group III.

While aiming to prepare detailed rules of procedure for use in resolving disputes in the field of e-commerce, the idea of establishing detailed rules of procedure was abandoned as a result of the legality of pre-dispute consumer arbitration agreements is handled differently in the various jurisdictions ${ }^{40}$. For example, while the EU member states and other countries did not allow for such binding procedures, the United States allowed for enforcement of pre-dispute arbitration agreements ${ }^{41}$. The basis of these disagreements was the regulation of consumer protection in national law and, in particular, the approaches that limit the arbitrability of consumer disputes. To address this

38 United Nations Commission on International Trade Law, 49th session, 'Report of Working Group III (Online Dispute Resolution) on the work of its thirty-third session', A/CN.9/868, 27 June-15 July 2016.

39 Amy J. Schmitz, “There's an “App” for That: Developing Online Dispute Resolution to Empower Economic Development", 2018, 32 Notre Dame Journal of Law, Ethics and Public Policy, p. 24.

40 Clara Flebus, "Report: UNCITRAL Working Group III on Online Dispute Resolution - A Change of Focus In The Outcome Document", 2016, 29, New York State Bar Association International Law Practicum, p. 60.

41 Noam Ebner and John Zeleznikow, "No Sheriff in Town: Governance for Online Dispute Resolution”, 2016, 32, Negotiation Journal, p. 297; Mireze Philippe, "ODR Redress System for Consumer Disputes: Clarifications, UNCITRAL Works \& EU Regulation on ODR", 2014, 1 International Journal of Online Dispute Resolution, p. 54; Schmitz, "There's an “App" for That", p. 23. 
matter, the Working Group stated two separate tracks; one track of which would end in arbitration and one track of which would not ${ }^{42}$. The United States favored Track One whereas the EU member states and other countries championed Track Two ${ }^{43}$. In 2014, the Working Group progressed to examine the draft document of the track of the rules that did not finish in a binding arbitration form which means Track Two ${ }^{44}$.

As a result, the UNCITRAL determined in its 48th session in July 2015 that there is no consensus in terms of ODR rules and requested from the Working Group III to prepare a non-binding text, which would only include basics of the ODR process that were previously agreed upon by the Working Group ${ }^{45}$. Finally, the Working Group III, acting under these instructions, prepared a guide document by excluding the arbitration stage which was considered as the final stage of ODR. The text was adopted at the 49th session of UNCITRAL in July 2016, under the name 'UNCITRAL Technical Notes on ODR'46.

The Technical Notes consist of 12 sections. For the purposes of the present article, instead of examining the whole document in detail, it is sufficient to explain the generally accepted principles concerning ODR. First of all, as stipulated in Section 4, the rules apply to disputes arising from cross-border, low-value e-commerce transactions ${ }^{47}$. Moreover, the Technical Notes state that an ODR process may be utilised to resolve disputes arising from B2B and $\mathrm{B} 2 \mathrm{C}$ transactions ${ }^{48}$. In the first section, general information about ODR is provided along with the purpose of the Technical Notes ${ }^{49}$. In this section, it is stated that ODR can be used as an effective method to resolve disputes arising from international internet transactions. By using ODR, disputes can be resolved in a simple, fast, flexible and secure manner without the parties having

42 United Nations Commission on International Trade Law, $30^{\text {th }}$ session, 'Report of Working Group III 'Online dispute resolution for cross-border electronic commerce transactions: draft procedural rules (Track II) `A/CN.9/WG.III/WP.130, 20-24 October 2014.

43 Ebner and Zeleznikow, p.297; Philippe, p. 54; Schmitz, "There's an "App” for That", p. 23.

44 United Nations Commission on International Trade Law, 30th session, "Online dispute resolution for cross-border electronic commerce transactions: draft procedural rules (Track II)", A/CN.9/WG.III/WP.130, 20-24 October 2014.

45 United Nations Commission on International Trade Law.

46 United Nations Commission on International Trade Law.

47 UNCITRAL Technical Notes on ODR, Section 4

48 UNCITRAL Technical Notes on ODR, Section 4(22)

49 UNCITRAL Technical Notes on ODR, Section 1 
to be physically present at a meeting or a hearing. In the same way, in Article 4 , it is stated that the ODR systems are based on the principles of impartiality, independence, efficiency, effectiveness, due process, fairness, accountability and transparency ${ }^{50}$. As stated in Article 2, the purpose of the Technical Notes is to assist the development and diffusion of ODR mechanisms that can be performed in many types, such as negotiation, mediation and arbitration. At this point, it is emphasised that Technical Notes is not a binding, but a descriptive document. It aims to resolve the low-value disputes arising from cross-border e-commerce transactions. For this purpose, the Technical Notes were intended to assist to third parties, ODR platforms and institutions that offer ODR services $^{51}$.

\section{ODR for Consumers in the EU}

In the EU, building consumer trust in online purchases has become one of the political goals of the European Commission. For building trust and providing effective dispute resolution system for consumer, the European Parliament and the Council adopted EU Directive on Consumer $\mathrm{ADR}^{52}$ and EU Regulation on Consumer ODR ${ }^{53}$ on 21 May 2013. The EU Directive on Consumer ADR obliges Member States to assure that quality ADR bodies that comply with procedural standards are available to consumers ${ }^{54}$. In February 2016, the EU Regulation on Consumer ODR established a web-based platform (EU ODR Platform), which enables the online submission of complaints and their transmission to the nationally approved ADR entities in the Member States. These two pieces of legislation have started a process that institutionalises and professionalises consumer ADR, becoming the main pillar of EU consumer redress law.

As mentioned earlier, the ODR Regulation sets an 'ODR Platform' that that is intended to facilitate an independent, impartial, transparent, effective, fast and fair out-of-court resolution of disputes between consumers and trad-

\footnotetext{
50 UNCITRAL Technical Notes on ODR, Section 1(4)

51 Mehmet Polat Kalafatoğlu, "Yabancı Unsurlu E-Tüketici Uyuşmazlıklarının İnternet Üzerinden Çözülmesi (Online Dispute Resolution) Konusunda Görüş, Düşünce Ve Öneriler”, 2018, 34 (2), Banka ve Ticaret Hukuku Dergisi, p. 301.

52 EU Directive on Consumer ADR 2013

53 EU Regulation on Consumer ODR 2013

54 EU Directive on Consumer ADR 2013 Articles 6-11
} 
ers $^{55}$. Since 15 February 2016, in order to achieve an increase of consumer trust in online sales, the ODR Regulation mandates that all online traders and intermediaries, which are established in the EU or Norway, Iceland or Liechtenstein, must provide an electronic link to the ODR platform on their websites ${ }^{56}$. When a consumer has a problem with the product or services, s/he clicks on the electronic link to access the ODR Platform and fills out a form, which is passed on to an online ADR service. The ODR Platform is available online at the 'Your Europe' website ${ }^{57}$. It is an interactive website, which can be accessed electronically and free of charge in 23 EU languages plus Norwegian and Icelandic. Therefore, the parties can submit their complaint(s) in their own languages on the Platform, which in turn can use a tool to translate what the party submits.

According to the ODR Regulation, the ODR platform shall be a single point of entry for consumers and merchants who want their disputes to be resolved out of court ${ }^{58}$. The ODR platform provides a free electronic case management tool that facilitates dispute resolution bodies to govern the dispute resolution procedure with the parties ${ }^{59}$. However, this does not mean that ADR is generally free of charge. A dispute resolution body may ask a consumer or a trader to pay a fee if it agrees to handle their case. There is no fixed fee as each dispute resolution body sets and charges a different fee.

\section{A. The Theoretical Framework (Administrative Functionality) of the EU ODR Platform}

Since the ODR Platform is only used for consumer disputes, in order to use the platform, a dispute has to arise between consumers and traders. In other words, the Platform is accessible for complaints arising from transactions between these two. Moreover, it is worth noting that the ODR Platform does not offer solutions to disputes arising from offline transactions ${ }^{60}$. So, the ODR

55 EU Regulation on Consumer ODR 2013, Article 1.

56 EU Regulation on Consumer ODR 2013, Article 14

57 See at EU Regulation on Consumer ODR 2013, Article 5; “Online Dispute Resolution” (2021) <https://webgate.ec.europa.eu/odr/main/index.cfm?event=main.home.show\&lng=EN $>$ Date of Access 7 April 2021.

58 EU Regulation on Consumer ODR 2013, Article 5(2).

59 EU Regulation on Consumer ODR 2013, Article Article 18 of the Preamble to the Regulation.

60 EU Regulation on Consumer ODR 2013, Article 2, 8 and 15 of the Preamble to the Regulation. 
Platform is only able to handle disputes arising from online sales and services. Not only disputes arising in cross-border online transactions but also disputes arising from domestic online transactions benefit from the ODR Platform ${ }^{61}$. The Platform does not accept complaints about higher education and healthcare services, even if the dispute arises from online transactions.

The ODR Platform can only be used if a consumer lives in the EU or in Norway, Iceland or Liechtenstein and the trader is based in the EU or in Norway, Iceland or Liechtenstein. As such, if either the trader or the consumer does not live in the EU, resolving their dispute through the platform would not be possible. In some countries (recently in Belgium, Germany, Luxembourg, Poland), traders can submit a complaint against a consumer. If a trader is not based in any of the Member States in the list, the trader cannot use the Platform to complain about a consumer. It should be noted that the Platform does not allow a consumer to complain about another consumer or a trader to complain about another trader.

There is no obligation on consumers or traders to use the ODR Platform, unless the parties have agreed, or some countries' legislation stipulates so. Moreover, in order to achieve an increase of consumer trust in online sales, the ODR Regulation mandates all online traders and intermediaries, which are established in the EU, must provide an electronic link to the ODR platform on their websites ${ }^{62}$. When a consumer has a problem with the product or services, he/she can click on the electronic link to the ODR Platform and fill out a form which is passed on to an online ADR service. However, there is a possible unintended consequence of Article 14, which is that the participation of online traders and intermediaries in ADR/ODR is non-mandatory when a consumer requests it. In other words, when a trader rejects to join an ADR/ODR process, the consumer complaint will be left unresolved. Because of this, the consumer would feel misled and lose their trust.

When a consumer fills out the complaint form and submits it to the platform, the complaint form is forwarded to the relevant merchant who recommends an ADR body to the consumer without delay ${ }^{63}$. Then, the relevant trader has 10 calendar days to respond to the consumer. If the trader agrees to

${ }^{61}$ EU Regulation on Consumer ODR 2013, Article 11 of the Preamble to the Regulation.

62 EU Regulation on Consumer ODR 2013, Article 14.

63 In the event that the complainant party is a trader, the complainant form is sent to the relevant consumer. 
take part in the process, $\mathrm{s} /$ he suggests one of the approved dispute resolution bodies detailed in the ODR Platform. Once the consumer and the trader reach an agreement on choosing the ADR body to settle their dispute, the ODR platform automatically communicates the complaint to the body ${ }^{64}$. Then, the ADR body settles the case completely online and reaches a decision in 90 days. It is worth noting that if the trader is not willing to use an approved ADR provider, the consumer does not reach agreement with the trader on which body will handle the complaint within 30 days after submitting the complainant or the ADR entity refuses to deal with the dispute, then the Platform will not be able to process the complaint any further ${ }^{65}$. If the consumer does not accept the suggested ADR entity, s/he can propose a different resolution body. If the other party accepts the suggested body, the process goes further, otherwise the complaint is closed.

Since launching the EU ODR Platform, all EU Member States, Liechtenstein and Norway have identified a number of dispute resolution bodies and a total of 468 ADR bodies can be accessed via the ODR platform (the highest number of them is in France with 87 and 52in the UK) ${ }^{66}$. Since February 2016, the Platform has received over 130,000 complaints, and, while $44.1 \%$ of these complaints are cross-border, the rest are national complaints ${ }^{67}$. While Germany and the UK are the countries where consumers lodged the most complaints on the platform, followed by France, Spain and Italy, most traders, against whom consumers submitted a complaint, are established in Germany, the UK and Spain, followed France and Hungary. (See table 1)

64 The dispute resolution body has three weeks to decide whether it is competent or not to deal with the dispute and inform the parties thereof.

65 EU Regulation on Consumer ODR 2013, Article 9 (8).

66 European Commission, 'Functioning of the European ODR Platform: Statistical Report' $<$ https://ec.europa.eu/info/sites/info/files/odr_report_2020_clean_final.pdf $>$ Date of Access 1 April 2021.

67 European Commission (Online Dispute Resolution 2020), 'Reports and statistics ` $<$ https:// ec.europa.eu/consumers/odr/main/?event=main.statistics.show $>$ Date of Access 1 March 2021. 


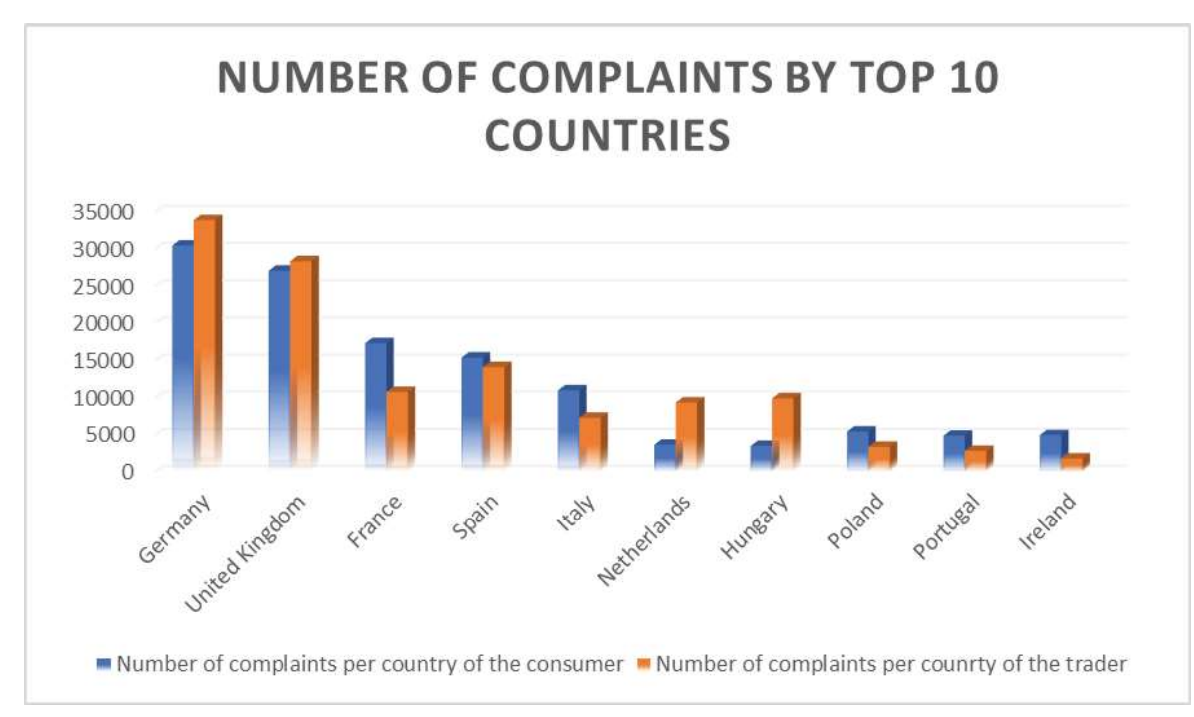

Table 1: Number of complaints by top 10 countries $^{68}$

According to the statistics given by the EU ODR Platform, up to date the retail sectors with the highest number of complaints were airline with $14,62 \%$, clothing and footwear with $10,40 \%$ and ICT goods with $6,54 \%$. (See table 2)

68 European Commission (Online Dispute Resolution 2020), 'Reports and statistics` $<$ https:// ec.europa.eu/consumers/odr/main/?event=main.statistics.show> Date of Access 1 March 2021. 


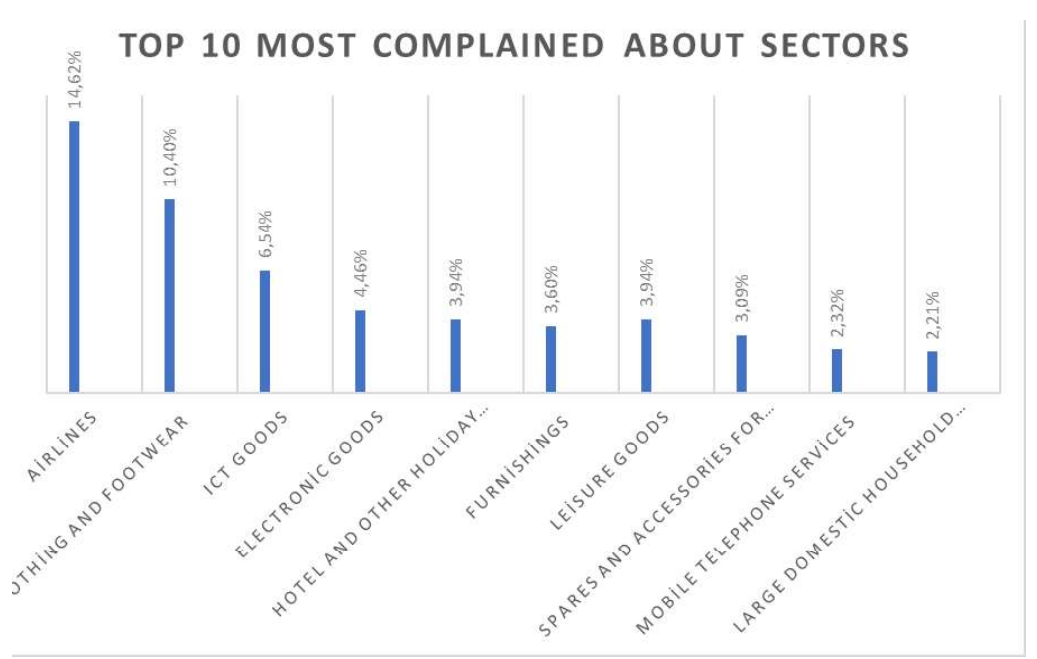

Table 2: Top 10 most complained about sectors ${ }^{69}$

\section{B. The Unintended Consequences of the EU ODR Platform}

The EU ODR Platform has potential for raising the awareness of consumers and increasing their access to justice as unawareness of their rights could discourage consumers from getting redress in low-value cross-border disputes $^{70}$. However, due to some essential limitations of the EU ODR Platform, it has not reached its own full efficiency and a number of criticisms have been expressed. One of the limitations of the ODR Platform is that, even though the Regulation makes providing a link to the Commission's website on traders' website mandatory for online traders, it is not mandatory for traders to participate in any ADR process. So, if a consumer submits a complaint against a trader, the trader is totally free to choose whether to participate in the ADR or refuse to consider the complaint. Moreover, when the trader refuses to participate, the consumer is not notified by neither ODR platform nor the trader. Consumers may only guess that the case is closed when they do not receive communication from the platform after 30 days of the complaint sub-

69 European Commission (Online Dispute Resolution 2020), "Reports and statistics" $<$ https:// ec.europa.eu/consumers/odr/main/?event=main.statistics.show $>$ Date of Access 1 March 2021.

70 Graham Ross, "The Possible Unintended Consequences of the European Directive on Alternative Dispute Resolution and the Regulation on Online Dispute Resolution", 2014, 10, Revista Democracia Digital e Governo Electrônico, p. 206. 
mission. The statistics, as given in the table below (table 3 ), show that $2 \%$ of the complaints reached a dispute resolution body after an agreement between the consumer and the trader and $81 \%$ of cases were automatically closed after the 30 days legal deadline ${ }^{71}$. It is worth noting here that, in order for the EU ODR Platform to be more efficient, it should be proposed that traders have to make either the platform or consumers aware by email whether or not they will participate in any ADR process. It will help the consumers know whether the case will proceed through ADR or not.

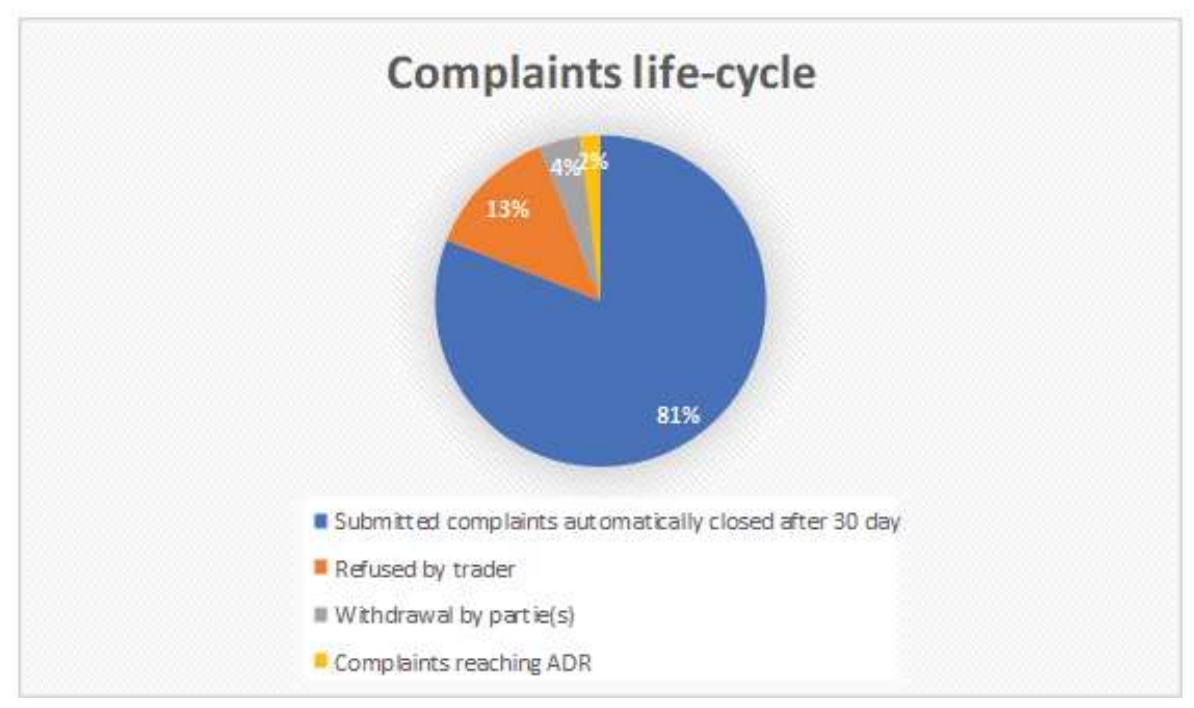

Table 3: Complaints life-cycle ${ }^{72}$

Another issue is that the platform requires filling the trader's email address which may be the only way to contact trader about the submitted complaint. However, consumers may encounter challenges in finding the correct trader's email address. Most of the times, the email addresses, which are used in the transactions are not appropriate email addresses to contact the traders

71 Ross, p. 206.

72 Report from The Commission to the European Parliament, the Council and The European Economic and Social Committee on the application of Directive 2013/11/EU of the European Parliament and of the Council on alternative dispute resolution for consumer disputes and Regulation (EU) No 524/2013 of the European Parliament and of the Council on online dispute resolution for consumer disputes $<$ https://eur-lex.europa.eu/legal-content/EN/TXT/ $\mathrm{PDF} /$ ?uri=CELEX:52019DC0425\&from $=\mathrm{EN}>$ Date of Access 5 April 2021. 
(they are often 'please do not reply' emails. Thus, it will be essential facility for consumers if the regulation requires traders to use the same email address used in the transactions.

The EU ODR platform should be more than just a referral site and present the following functions ${ }^{73}$. Firstly, the issue identification and dispute prevention function should encourage early settlement by automatically providing custom-made information about the rights and obligations of the consumers ${ }^{74}$. Secondly, the platform should offer an online negotiation tool that provides consumers and traders with a forum to handle complaints before dispute resolution bodies participate in the process ${ }^{75}$. Finally, a full referral function should be designed not only to send an invitation to both parties to choose a dispute resolution body, but also to automatically escalate the dispute to resolution body when the parties fail to reach an agreement through online negotiation and the trader is signed to an ADR process ${ }^{76}$. In the event of an unresolved dispute, the consumer should be assisted in referring the case to the courts.

Moreover, the platform requires all consumers and traders to submit a complaint only for goods or services they bought online. In other words, the platform is not used for complaints about good or services bought physically in a shop ${ }^{77}$. Considering that the aim is to overcome physical barriers and boost consumer confidence in online transactions, in particular cross-border transactions, the use of the platform on only online transactions seems absolutely reasonable and justified. However, it should be proposed that the platform should allow users to submit a complaint even when they bought something offline at least for domestic disputes.

Last but not least, the use of the platform is totally free, but a dispute resolution body may ask consumers and traders to pay a fee for handling their disputes. Generally speaking, the dispute resolution bodies usually state that no fee has to be paid by the consumers. However, the traders may have to pay a fee, which varies depending on the case. This pecuniary obligation may be

\footnotetext{
73 Kaya, p. 89-92; Pablo Cortes, The Law of Consumer Redress In An Evolving Digital Market: Upgrading from Alternative to Online Dispute Resolution, Cambridge University Press, 2018, p. 99. 
one of the strongest reasons that traders implicitly or explicitly do not participate in any ADR process. Thus, it should be proposed that the platform should offer consumers and traders to resolve their dispute by using online negotiation.

\section{The Need for Re-designed of the EU ODR Platform}

The ADR Directive and the ODR Regulation are considered to be significant steps forward in the direction of building an adequate EU legal framework for consumer disputes and fulfilling the requirements for the operation of the EU internal market. These legal instruments significantly affect cross-border disputes and, as a result, it is necessary to examine not only how each Member State has implemented them and whether harmonisation can be achieved, but also evaluate their effectiveness with regard to cross-border disputes which may appear within the Single Market ${ }^{78}$.

While this paper identifies the positive aspects of the legal developments made so far, it argues that there are still some objectives, which are set out by the Commission that should be met in order to enable the EU ODR Platform to reach its full efficiency ${ }^{79}$. For example, online traders, who have been established in the EU, are obliged to inform consumers about the EU ODR Platform by providing a link on their websites, however they are not obliged to get involved in the process and in most cases disputes with consumers are left unresolved ${ }^{80}$. Thus, consumers, who have submitted a dispute that has not been resolved through online negotiation, should be able to refer it to the relevant dispute resolution body to be resolved. The paper suggests that the EU ODR Platform should be more than just a referral site and have the following functions: First, issue identification and dispute prevention function, which should encourage early settlement by automatically providing custom-made information about the rights and obligations of the consumers ${ }^{81}$. Second, the Platform should offer an online negotiation tool that would provide consumers and related traders with a forum to handle complaints before dispute resolution bodies get involved in the process. Finally, a full referral function that should be designed not only to send an invitation to both parties to choose a dispute resolution body, but also to automatically escalate the dispute to a

78 Cortes, The Law of Consumer Redress In An Evolving Digital Market, p. 99.

79 Cortes, The Law of Consumer Redress In An Evolving Digital Market, p. 99; Ross, p. 206.

80 Kaya, 89-92.

81 Cortes, The Law of Consumer Redress In An Evolving Digital Market, p. 99. 
resolution body, when the parties fail to reach an agreement through online negotiation. In the case of unresolved disputes, consumers should get help in the process of referring the case to the court.

\section{Feasibility Analysis of ODR in Turkey}

\section{A. Current Consumer Enforcement and Dispute Resolution Processes in Turkey}

It is obvious that access to justice and having appropriate mechanisms for resolving disputes are fundamental rights of consumers ${ }^{82}$. In the Turkish legal system, the Code of Civil Procedure is the primary law, which determines the redress system for resolving disputes and states the scope, subjects and procedure of resolution of disputes. The procedural rules and principles regarding the consumer disputes can be found in the CPL. Articles 66 to 72 of the Law regulate consumer arbitration boards ${ }^{83}$, which are established by the Ministry Trade that have the authority to resolve disputes up to a certain economic threshold ${ }^{84}$ and make binding decisions in these disputes. Articles 73 and 74 set the consumer courts, which are authorised to resolve disputes above the threshold and operate as the appeal authority for the decisions of the consumer arbitration boards. Recently, on July 28, 2020, the Law Amending the Civil Procedure Law and Certain Laws numbered 7251 added 'Article 73/A', 'Mediation as a prerequisite', to the Consumer Protection Law Numbered 6502 stating that going to mediation is a prerequisite to file lawsuits for consumer disputes involving monetary claims of TRY 11,330 and above ${ }^{85}$.

82 This point was stated by the "Council resolution of 14 April 1975 on a preliminary programme of the European Economic Community for a consumer protection and information policy OJ 1975, No.C92/1".

83 For detailed discussion on consumer arbitration boards see Ali Cem Budak, "Tüketici Hakem Heyetleri”, 2014, 16, DEÜHFD, Pekcanıtez Armağanı, p. 77-103; İbrahim Ermenek, "Yargı Kararları Işığında Tüketici Sorunları Hakem Heyetleri ve Bu Alanda Ortaya Çıkan Sorunlara İlişkin Çözüm Önerileri”, 2013, 17, Gazi Üniversitesi Hukuk Fakültesi Dergisi, p. 574; Bilgehan Yeşilova , “6502 sayılı Yeni Tüketicinin Korunması Hakkında Kanun'a Göre Tüketici Uyuşmazlıklarının Çözümü Usulü ve Yargılama Kuralları”, 2014, 9, Terazi Hukuk Dergisi; Hakan Pekcanıtez, “Tüketici Sorunları Hakem Heyeti”, 1996, Izmir Barosu Dergisi, p. 41-42; Mehmet Akif Tutumlu, Tüketici Sorunları Hakem Heyetlerinin Yapısı, İşleyişi, Sorunları ve Çözüm Önerileri, Seçkin, 2006, p. 37-39.

84 This monetary threshold is determined and announced each year in the Official Gazette by the Ministry of Trade. See CPL Article 68, and the Regulation on Consumer Arbitration Board Article 6.

85 CPL Article 68, and the Regulation on Consumer Arbitration Board Article 6. 


\section{B. Online Access to Consumer Arbitration Boards and Consumer Courts}

The Turkish Ministry of Justice has developed a 'National Judiciary Informatics System (UYAP)' since 1998 to perform a particularly driving information system between the courts and all other judicial institutions, including prisons to improve the speed, reliability and performance of the judicial service offered to citizens in digital age. UYAP has been implemented these institutions with ICT and gives them access to all the legislation, the judicial decision of the Cassation Court, judicial records, police and military record judicial data. In this way, UYAP builds a computerised system incorporating all courts, prosecutorial offices, and law enforcement agencies, along with the Central Organization of the Ministry of Justice. Thanks to UYAP, both lawyers and citizens who can connect to UYAP Lawyer or Citizen Portal with using their e-signature or mobile signature ${ }^{86}$, can file a suit in civil courts, examine all their judicial and administrative cases, pay their case fee, commence execution proceedings, submit any related documents and question the situation of the cases in the Court of Cassation and Council of State through online. The latest data shows that the number of active users of the portal has reached the significant amount with more than 4.2 million, approximately 16 million cases fees have been paid by online, more than 12 million successful transactions regarding either filling cases or execution proceedings have occurred, and lastly over 125 million documents have been submitted to courts though using that online portal ${ }^{87}$.

With regards to consumer disputes fall within the remit of consumer courts, consumers can file a suit to consumer courts through online by using their e-signature or m-signature since 2015. Citizens who want to submit or follow their case in electronic environment can access UYAP Citizen Portal Information System at https://vatandas.uyap.gov.tr/vatandas/index.jsp. Consumers who want to log in to the Portal via e-signature or m-signature, can access the cases and enforcement proceeding in consumer courts, examine the contents of all the submitted documents in the case, calculate the fees and expenses to be paid related to the lawsuit. Citizens who do not have an e-sig-

86 While electronic signature is presented by Electronic Certificate Service Providers approved by Information Technologies and Communication Authority, mobile signature is serviced by mobile network operators in Turkey.

87 UYAP Bilişim Sistemi, (2018), <https://avukat.uyap.gov.tr/main/avukat/index.jsp?v=3015> Date of Access 12 March 2021. 
nature or a mobile signature can use the e-government gateway to only view the main safeguard information of the case files in the consumer courts under UYAP and cannot submit a case to courts through Internet. Thus, e-signature or m-signature is required in order to file a suit or take action online.

Lastly, previously, applications to Consumer Arbitration Boards that can be made by personally or by mail can now also be easily done electronically since $2017^{88}$. It has become possible for consumers to submit their applications from the relevant screen after logging in with the e-Government passwords. Users can go to 'Consumer Complaints Application' and go to 'Consumer Complaints Applications' step. As a result of this application, consumers are not obliged to apply to courts or Arbitration Boards in person for low value claims anymore, and they can make their applications online. This possibility encourages consumers who think that it is not time efficient to go to court in person for low value claims, to defend their rights.

\section{Development of an ODR System in Turkey}

In the current digitalised society, there is a strong possibility that ODR will become a significant dispute resolution mechanism to resolve disputes. Turkey should take legal action and practice upon promoting a proper ODR system for low-value disputes ${ }^{89}$. The advancement of an ODR system for resolving disputes regarding online Business to Consumer (B2C) sales would be a good starting point. Subsequently, such a system could be adopted for any consumer disputes, including arising from offline transactions ${ }^{90}$. Developing an ODR system for online transactions is suitable given that the purchases are performed online, the value of consumer transactions is usually low, online buyers inspire confidence in the online retailer by transferring money before receiving the items, and they cannot usually return them to a store when problems appear.

Instead of reinventing the wheel, Turkey can utilise the initiatives made by the EU and UNCITRAL, such as the EU ODR Platform and take them for-

88 The Regulation on the Amendment of the Law on Consumer Arbitration Boards was published in the Official Gazette and entered into force on 11 August 2017, <http://www.resmigazete.gov.tr/eskiler/2017/08/20170811-1.htm> Date of Access 4 April 2021.

89 İnan Uluç, Online Uyuşmazlık Çözümü, 2015, Prof. Dr. Ramazan Arslan'a Armağan, p. 1609-1643.

90 Conclusively, disputes arising from offline transactions should have been resolved by the same systems that are available to consumers who have disputes arising online. 
ward $^{91}$. The schemes developed by the EU and UNCITRAL need the founding of an ODR platform which would serve as an entry point for disputes and inform disputants. Any ODR platform established in Turkey should include a tiered system, which, as recommended by the UNCITRAL Technical Notes on ODR, would encourage disputants to negotiate for reaching an agreement before their disputes are referred to mediation or arbitration. In the event that the trader and consumer cannot resolve their disputes amicably using assisted negotiation, the second step would be to forward disputes to the ADR schemes to be resolved.

D. A Proposal for Creating Non-Profit ODR Platform: How could ODR Platform operate in Turkey?

The ODR platform in Turkey is set in a way comparable to the ODR Regulation 2013 and the UNCITRAL Technical Notes and it should follow the steps below:

1. Problem Diagnosis and Conflict Prevention Function: Problem diagnosis should help parties identify the type of disputes they have $\mathrm{e}^{92}$. The Platform should assist in understanding what the parties' legal rights and liabilities are. For example, summaries of decisions in similar disputes can help. A useful knowledge tool should organise the content according to different types of disputes and serve as a diagnostic or information management tool that would prevent unmeritorious disputes. This function will be more effective if Turkish consumer advisory centres and another related department connect to the ODR platform. In addition, universities, consumer unions and associations can collaborate with advisory centres to provide support for consumers who have difficulties using the ODR platform. One advantage of handling high-volume e-commerce disputes is that these disputes can simply be categorised and settled when disputants reach an agreement concerning the applicable law on their disputes that is unambiguous. Most disputes arising from the purchase of items regard non-delivery, late delivery or not matching the seller's description and payment.

\footnotetext{
91 A similar way was suggested for New Zealand. See Trish O'Sullivan, "Developing an Online Dispute Resolution Scheme for New Zealand Consumers Who Shop Online-Are Automated Negotiation Tools the Key to Improving Access to Justice?", 2015, 24, International Journal of Law and Information Technology, p. 22.

92 Cortes, The Law of Consumer Redress in an Evolving Digital Market, p. 125.
} 
The platform should categorise disputes into a well-organised taxonomy so that when the information is processed, it should be shared with related traders and competent authorities that will be able to evaluate what is going on in the markets. Based on this shared information, legislators and traders would respond to market difficulties that require to be tackled. Although regulators will control law compliance and reduce the cost of public enforcement, traders will benefit from this information by improving their market standards and preventing future consumer disputes.

2. Submit Complaint and Response: The consumer submits a complaint against the online trader via the ODR platform by filling a form and providing the detail of the disputes, such as the name of traders, traders' email address, and description of the dispute. At this stage, some satisfactory solutions for the consumer may be offered by the Platform. It is worth mentioning that the consumers should contact the traders themselves to resolve their disputes before applying to the Platform. If not, the Platform may refuse their applications and ask them to contact the traders first. A fully completed complaint form would be forwarded automatically to the relevant trader by the Platform and the traders would be expected to respond to the consumers with proposed solutions. The relevant trader should have seven calendar days to reply or offer a solution to the consumer.

3. Negotiation Stage: The negotiation stage can be improved by automated negotiation tools, which recognise areas of agreement and dispute. The computerised machines then help in creating a conversation between the disputants which aims to push them towards a satisfactory agreement through facilitating an exchange of views, insulating issues of controversy and classifying proposed solutions.

4. Referring the Dispute to the Convenient Dispute Resolution Bodies: If parties do not resolve their disputes by negotiating within 10 calendar days, the dispute may be referred to be settled by other ADR entities. It is worthy note here that the proposed Platform does not prescribe a specific type of ADR methods. Any convenient ADR methods (including arbitration) allowed by national law may be utilised for settlement or resolving consumer disputes. Because of the characteristic of consumer disputes (usually are low-value), online 
negotiation and online mediation are better to fit the $\mathrm{B} 2 \mathrm{C}$ context ${ }^{93}$. Complexities of arbitration, cost of arbitration and continual debate regarding the arbitrability of consumer disputes in Turkey may make arbitration less preferred ADR methods for consumer disputes. This platform can benefit from the well-established ODR practices such as eBay, SquareTrade, SmartSettle, CyberSettle, AAA and CIETAC Online Dispute Resolution Center.

5. Escalating the Dispute to an Online Judicial Process: If parties do not settle their disputes through ADR entities within 30 days, as a final stage the dispute should be referred to either online consumer arbitration boards or consumer courts depending on the value of claim. The platform should minimise the number of disputes referred by trying to resolve them at early stages.

The cost of establishing and conducting the ODR Platform as a starting point for online consumers, would require to be supported and financed by the government and could be supervised by the Ministry of Justice and Ministry of Trade. The Ministry of Justice will have the task of improving and providing an effective redress system that would keep pace with the needs of the citizens living in the current globalised and digitalised era for ${ }^{94}$. The cost of establishing an ODR platform can be sustained because the goal of the ODR system is to increase consumers' access to justice and provide a cost-effective and time-saving method of dispute resolution. When the ODR platform starts to run, online businesses could be obliged to pay a fee to promote the platform, and online consumers may be asked to be charged a small fee (perhaps 1-5\% of the value of the claim) to submit their complaints online. If disputants do not resolve their disputes at the negotiation stage, the trader could be charged with a fee which would cover the cost of selecting an ADR entity to settle the dispute. It is worth noting that going to consumer arbitration boards and con-

93 Philippe, p. 54; Schmitz, "There's an “App”, p. 23.

94 In many official reports and publications containing proposals for increasing effectiveness in justice systems, for example the recent report entitled 'Ministry of Justice Strategic Plan 2015-2019' published by the Republic of Turkey's Ministry of Justice (Directorate for Strategy Development), it is mentioned that it has become increasingly inevitable to improve the ADR methods and to enhance the effectiveness in practice. See 'Ministry of Justice Strategic Plan 2015-2019' published by Republic of Turkey Ministry of Justice, Directorate for Strategy Development (2015), <http://www.judiciaryofturkey.gov.tr/pdfler/plan.pdf $>$ accessed 7 April 2021; moreover, in 2010 the Judicial Reform Strategy and the Strategic Plan of Ministry of Justice and recently the Tenth Development Plan (2014-2018) have been prepared by the Grand National Assembly of Turkey, state that ADR mechanisms will be given priority. 
sumer courts is free of charge ${ }^{95}$. Thus, it will more likely be discouragement for submitting the complaint to ODR Platform if consumers are asked to pay a fee. At the same time, requesting the fee of the process to be paid by traders can result in traders not accepting to participate in the process and simply refuse the request ${ }^{96}$. In this case, it is necessary to find alternative solutions to both make the use of the ODR effective and encourage traders to participate in process. It is suggested that the use of artificial intelligence software, such as case profiling, knowledge management which automatically examine the characteristics of individual claims, would not only reduce the cost but also enhance the actual quality and compatibility of resolutions ${ }^{97}$.

Another funding possibility is EU projects. For example, the recent project entitled the 'Technical Assistance for Strengthening Consumer Protection' which is funded under the EU's Instrument for Pre-Accession, has started to provide effective consumer protection in line with the EU acquis and Member States' best practices ${ }^{98}$. One of the objectives of the project is to increase the effectiveness and applicability of Consumer Arbitration Boards, remodel the consumer arbitration boards' system and establish efficient ADR entities under a clear regulatory regime by conducting surveys, organising campaigns, preparing workshops, seminars, evaluation reports and giving training.

As a starting point, a launched ODR platform should be accessible for consumers, who live in Turkey, against online traders who are based in Turkey. The main reason to restrict it to traders based in Turkey is that jurisdiction problems will occur regarding traders based outside Turkey if it is allowed to submit complaints against them as well. It does not seem easy to force such

95 In Turkey, in accordance with the Consumer Protection Law any consumer disputes are taken to consumer courts by the consumers, consumer associations and Ministry of Trade are exempted from case fees. However, they may be charged for post and expert fees. It is important to mention that bringing disputes to consumer arbitration boards are totally free of charge for consumers. If consumer arbitration boards need an expert, the fee for this expert is paid by the Ministry of Trade.

96 A proportionate fee can be requested from the traders for the platform. Similar to the European Small Claims Procedure approach concerning the fee, a calculation method can be established to determine the proportionality of fees, for example ODR entities fees of less than $15 \%$ of the value of the claim can be considered as proportionate.

97 Ross, p. 217.

98 The project has a total budget of 2 million euros, out of which 1.8 million euros are provided by the EU. See Consumer Protection, A Common Priority! (EU Delegation to Turkey, 2018), $<$ https://www.avrupa.info.tr/en/pr/consumer-protection-common-priority-7765> Date of Access 4 April 2021. 
traders to be involved with this ODR platform ${ }^{99}$.

\section{The Need for a Policy and Regulation}

Similar to the provisions of the ODR Regulation 2013, online merchants should be obliged by law to inform consumers concerning the ODR Platform and give a link to connect to the ODR platform's website. It is worth noting here that the provided link should be visible in the website. ${ }^{100}$ If the ODR platform is intended to be successful in Turkey, the law should make it mandatory for disputants to join and use this process. In this way, there will be awareness about the Platform and ODR procedures will be promoted and become more popular. In other words, parties will learn and observe what the ODR itself is and how it works. A significant shortcoming of the EU ODR Regulation is that traders can refuse to participate in or ignore the ODR procedure. Similar to the UNCITRAL Technical Notes on ODR ${ }^{101}$, law may stipulate that if the disputants fail to resolve their disputes themselves and choose an ADR entity within reasonable time, then the ODR manager can select an ADR entity for reaching a settlement. In the event of failure to choose an ADR entity, the ODR administrator is expected to determine as to whether the entity shall be replaced. As a practical matter, the law should also require online businesses to provide a contact email address on their websites and use the same email address used in their transactions with customers. Some of them only allow communication via filling online forms and do not provide an email address. Moreover, most of times the email addresses, which are used in their transactions, are not proper email addresses that can be used to contact the traders (they are often 'please do not reply' emails). If consumers submit a complaint via the platform, they should be given a contact email address of the traders so that the Platform can forward the complaint to the trader.

99 These jurisdiction issues are beyond the scope of this article. In order to see legal challenges of international consumer disputes, see Kaya, p.128-150.

100 Although the European Union has made it a legal requirement to provide the link in the websites, there is no arrangement on how this link can be shown to users. Most of times, it is not visible in their websites.

101 The Technical Notes recommends that the ODR administrator should choose a neutral that interacts with the litigants in an attempt to resolve the disputes. See UNCITRAL Technical Notes on ODR, Article 20. 
Access To Justice For Consumers In Turkey: The Need For Enhancing ...

\section{The Need to Raise Awareness of Consumer Regarding ADR and ODR}

A difficulty encountered by Turkish consumers is to familiarise themselves with the notion of ADR and ODR as well as with ADR entities. A report conducted in 2107 and entitled 'the Project on the Development of Mediation in Legal Disputes ${ }^{\prime 102}$ has surprisingly stated that the court officers' awareness about mediation is only less than $4 \%{ }^{103}$. The other astonishing figure is that only $24 \%$ of the members of the Confederation of Turkish Tradesmen and Craftsmen and Turkish Union of Chambers and Commodity Exchanges admitted that that they have knowledge about mediation ${ }^{104}$. The Department of Mediation has created a website with the links of the public mediation centres and the lists of individual mediators ${ }^{105}$.

The disputants, traders and consumer unions and associations, such as the Confederation of Turkish Tradesmen and Craftsmen and Turkish Union of Chambers and Commodity Exchanges or arbitration institutions, meditation centres, government agencies, particularly the Department of Mediation, may refer disputes to certified ODR entities. When this takes place through the ODR entities' website, the principal scheme practised is synchronise with Trustmark. Hence it is a necessity for the identification and establishment of a framework of Trustmark in Turkey.

\section{E. A Proposed Model to Raise the Effectiveness of Current Turkish Consumer Redress System}

As mentioned above, consumers in Turkey generally go to consumer arbitration boards or consumer courts for resolving their disputes ${ }^{106}$. Even though

102 This project is co-funded by the Swedish International Development Cooperation Agency and the Republic of Turkey and implemented by the European Council. See The Project on the Development of Mediation in Civil Disputes (2017) $<\mathrm{https} / / \mathrm{rm}$.coe.int/mediation/ $168075 \mathrm{fa} 4 \mathrm{c}>$ Date of Access 5 April 2021.

103 The Project on the Development of Mediation in Civil Disputes (2017), <https://rm.coe.int/ mediation/168075fa $4 \mathrm{c}>$ Date of Access 5 April 2021.

104 The Project on the Development of Mediation in Civil Disputes (2017), <https://rm.coe.int/ mediation/168075fa $4 \mathrm{c}>$ Date of Access 5 April 2021.

105 The Department of Mediation <https://adb.adalet.gov.tr/Home/> Date of Access 11 April 2021.

106 For disputes exceeding 11.330 Turkish Lira, consumer courts have jurisdiction. Lower disputes are typically taken to Consumer Arbitration Boards. If the value of the dispute is under the monetary threshold, it is mandatory to apply to board before applying to Consumer 
the consumer redress system and other legislative instruments have had positive results, there are still problems in the use of current system, which do not allow it to reach its full efficiency. One of these is the unpredictability of the time employed for resolving low-value disputes. The Law on Consumer Arbitration Boards stated that after the submission of the dispute, the boards shall start to resolve the dispute within six months ${ }^{107}$. Similarly, the report carried out by Ministry of Justice stated that the average duration of a case in consumer courts is 425 days. This time period may be considered excessive for specific types of consumer disputes, especially low-value disputes arising from e-commerce ${ }^{108}$. In the event that a consumer submits his/her complaint about a pair of shoes worth 300 Turkish Lira through the Consumer Arbitration Board, the Board has to resolve the dispute within 180 days. Therefore, the fact that a dispute will be handled and resolved in 180 days by the Board may discourage consumers to use this system for low-value disputes. When it is compared to the length of time taken by some accomplished ODR schemes, such as eBay's Resolution Centre or Modria, where the expected period for handling and resolving disputes is less than 10 days, it becomes apparent that the difference is substantial ${ }^{109}$. An empirical research conducted in eBay users showed that the existence of an effective consumer redress system helping users in resolving their disputes has a favourable effect on the activity of users ${ }^{110}$. That is to say, these users, who had claimed and were given efficient redress, had increased more activities afterwards than those who did not have any claims. Thus, the Consumer Protection Law should be amended so that the board and the courts shall resolve disputes within maximum 90 days.

Court. Similarly, if the claim is over the monetary limit, it has to be taken to the consumer courts.

107 However, in some cases (taking into account such factors as the nature of the application, the application, the nature of the goods or services) the period can be extended for a maximum of six months. For instance, in the case of the claimant is foreign. See the Regulation on Consumer Arbitration Committee for Consumers Article 23.

108 Ross, p. 218.

109 Colin Rule, "Quantifying the Economic Benefits of Effective Redress: Large E-Commerce Data Sets and the Cost-Benefit Case for Investing in Dispute Resolution", 2012, 34, University of Arkansas Little Rock Law Review, p. 767, 776.

110 Colin Rule, "Quantifying the Economic Benefits of Effective Redress: Large E-Commerce Data Sets and the Cost-Benefit Case for Investing in Dispute Resolution", 2012, 34, University of Arkansas Little Rock Law Review, p. 767, 776. 
Access To Justice For Consumers In Turkey: The Need For Enhancing ...

Another problem with the system is that the Turkish Consumer Protection Law states that the Board consists of five members ${ }^{111}$. Having so many board members for resolving low-value disputes may cause delays in the award of justice. Larger boards tend to meet less often because it is not easy to coordinate all members' busy calendars. Board discussions are generally longer and less focused than those of smaller boards, which typically results in slow decision-making ${ }^{112}$. While, in practice, the number of arbitrators in commercial disputes is usually one or two, it is questionable to expect that five board members deal with submitted consumer disputes which are less complicated than commercial disputes. It is suggested that the number of board member should be reduced and be limited to a maximum of three members.

Another obstacle identified by research is the lack of awareness about the way of applying to consumer arbitration boards and consumer courts. Complaints to the Consumer Arbitration Boards can be easily submitted electronically since 2017 and consumers can file a suit to the consumer courts online since 2015. Parties usually encounter difficulties regarding the time required for travelling, and there is a lack of transparency about the details of the procedure. As a consequence, not only vulnerable consumers, but a large part of society may not understand the system as an accessible redress option. In order to raise the awareness of the consumers regarding the use of electronic communications in submitting complaints to either the boards or courts, similar to the ODR Regulation 2013, online merchants should be obliged by law to inform consumers about the consumer arbitration boards and consumer courts and give them a link to connect to the Consumer Information System and Citizen Portal.

\section{Conclusion}

In this article the scenery of ODR was introduced and explored, with reference to it's the main difficulties it requires to overcome for becoming more prevalent in Turkey. Despite its incomplete development, ODR has demonstrated its potential adaptability by accommodating to national contexts. This is an essential feature because the aim is not to blindly transfer a dispute resolution system from other jurisdictions, but to habilitate it to the national cultural features as well as social limitations, especially those regard-

111 Article 66(2) of the CPL.

112 Marcia Blenko, Michael C. Mankins and Paul Rogers, Decide and Deliver: Five Steps to Breakthrough Performance in Your Organization, Harvard Business Review Press, 2010. 
ing ICT infrastructure. ODR has also showed its great potential in Turkey, may provide an affordable and speedy alternative to the usually unsatisfying traditional litigation system and may allow the resolution of disputes to be completed time-efficiently and cost-effectively. As stated above, some empirical researches clearly show that an effective consumer redress system helping users in resolving their disputes has a favourable effect on the activity of users. If Turkish manufacturers or service providers provide an effective consumer redress system through ODR, which means buyers will have a better experience on manufactures, consumer may continue to purchase items on manufactures again. In other words, in order to build consumer trust and assist in developing a reliable and competitive market, manufactures should provide an effective redress system.

This article has explored the need for designing a Turkish legal framework in the field of ODR. This section suggested the creation of an ODR scheme, which can be modelled on the work done by well-functioned ODR providers. The core element to develop a cost-effective, efficient and successful ODR mechanism will be the incorporation of automated negotiation tools in the ODR process to resolve disputes at an early stage before escalating to either dispute resolution bodies or consumer arbitration boards or consumer courts. The cost of establishing and operating the ODR platform should be supported by the government under the supervision of the Ministry of Justice and Ministry of Trade. In order to raise awareness of consumers, online merchants should be obliged by law to inform consumers about the ODR platform and provide a visible link for them to connect the ODR platform website. The law should make the participation to the ODR platform mandatory for disputants. Through such a regulatory framework that would oblige parties to consider the ODR procedure at least for some of their cases, ODR will be promoted and become more popular. The article suggested that the Department of Mediation should establish the legal ground of or at least support the establishment of private accredited dispute resolution bodies in Turkey. Finally, the article emphasised that the consumer unions and associations, such as the Confederation of Turkish Tradesmen and Craftsmen and Turkish Union of Chambers and Commodity Exchanges, or arbitration institutions, meditation centres, government agencies, particularly the Department of Mediation, should make strategic alliances with the Ministry of Trade to raise the awareness of ODR and channel disputes to certified ODR providers. 


\section{Bibliography}

Abdel Wahab M S, Katsh E and Rainey D, ODR: Theory and practice, 2nd edn, Eleven International, 2021.

American Bar Association's Task Force on Electronic Commerce and Alternative Dispute Resolution in Cooperation with the Shidler Centre for Law, Commerce and Technology, University of Washington School of Law, 'Addressing Disputes in Electronic Commerce: Final Recommendations and Report', 2002, 58, Business Lawyer, p. 415-477.

American Bar Association Task Force on E-Commerce and ADR Executive Summary of Final Recommendations, Final Report, August 2002.

Betancourt J and Zlatanska E, "Online Dispute Resolution (ODR): What Is It, And Is It the Way Forward?", 2013, 79, International Journal of Arbitration, Mediation and Dispute Management, p. 256-254.

Blenko M, Mankins M C and Rogers P, Decide and Deliver: Five Steps to Breakthrough Performance in Your Organization, Harvard Business Review Press, 2010.

Budak A C, “Tüketici Hakem Heyetleri”, 2014, 16, Dokuz Eylül Üniversitesi Hukuk Fakültesi Dergisi, Pekcanıtez Armağanı, p. 77-103.

Cole S R and Blankley K M, "Online Mediation: Where We Have Been, Where We Are Now, and Where We Should Be", 2006, 38, U. Tol. L. Rev., p. 193.

Consumer Protection, A Common Priority! (EU Delegation to Turkey, 2018), $<$ https://www.avrupa.info.tr/en/pr/consumer-protection-commonpriority-7765> Date of Access 4 April 2021.

Cortés P, The Law of Consumer Redress in An Evolving Digital Market: Upgrading from Alternative to Online Dispute Resolution, Cambridge University Press, 2018.

Cortés P, Online Dispute Resolution for Consumers in the EU, Routledge, 2011.

Cortés P and Lodder A, "Consumer Dispute Resolution Goes Online: Reflections on the Evolution of European Law for Out-Of-Court Redress", 2014, 21 (1), Maastricht Journal, p. 14-38.

Directive 2013/11/EU of the European Parliament and of the Council of 21 
May 2013 on alternative dispute resolution for consumer disputes and amending Regulation (EC) No 2006/2004 and Directive 2009/22/EC, OJ L165/63, 18 June 2013.

Ermenek I, "Yargı Kararları Işı̆̆ında Tüketici Sorunları Hakem Heyetleri ve Bu Alanda Ortaya Çıkan Sorunlara İlişkin Çözüm Önerileri”, 2013, 17, Gazi Üniversitesi Hukuk Fakültesi Dergisi, p. 563-634.

Ebner N, Zeleznikow J, "No Sheriff in Town: Governance for Online Dispute Resolution", 2016, 32, Negotiation Journal, p. 297-323.

Eisen J B, “Are We Ready for Mediation in Cyberspace?”, 1998, 4, Brigham Young University Law Review, p. 1305-1360.

Ercan M, Uyuşmazlıkların Online Çözüm Yöntemleri, LLM Thesis, 2012.

European Commission, "Functioning of the European ODR Platform: Statistical Report", <https://ec.europa.eu/info/sites/info/files/odr_ report_2020_clean_final.pdf $>$ Date of Access 1 April 2021.

European Commission (Online Dispute Resolution 2020), "Reports and statistics", $\quad<$ https://ec.europa.eu/consumers/odr/main/?event=main. statistics.show $>$ Date of Access 1 March 2021.

European Commission (Online Dispute Resolution 2021), $<$ https://webgate. ec.europa.eu/odr/main/index.cfm?event=main.home.show\&lng=E $>$ Date of Access 7 April 2021.

European Commission for the Efficiency of Justice (CEPEJ) "European judicial systems, efficiency and quality of justice: Use of information technology in courts in Europe", CEPEJ Studies No. XX, 2016 edition (2014 data).

Farned D B, “ANew Automated Class of Online Dispute Resolution: Changing the Meaning of Computer-Mediated Communication", 2011, 2, Faulkner Law Review, p. 335-360.

Flebus C, "Report: UNCITRAL Working Group III on Online Dispute Resolution - A Change of Focus In The Outcome Document", 2016, 29, New York State Bar Association International Law Practicum, p. 60.

Hörnle J, Cross-border Internet Dispute Resolution, Cambridge University Press, 2009.

Kadığlu C Ç, "Bricks and Clicks: Online Dispute Resolution Mechanisms 
and Implementation of Online Arbitration in Turkey for Cross-Border Business to Consumer E-Commerce Disputes”, 2019, 1, ASBÜ Bilişim Hukuku Dergisi, p. 113-146.

Kalafatoğlu M P, "Yabancı Unsurlu E-Tüketici Uyuşmazlıklarının İnternet Üzerinden Çözülmesi (Online Dispute Resolution) Konusunda Görüş, Düşünce Ve Öneriler”, 2018, 34 (2), Banka ve Ticaret Hukuku Dergisi, p. 301-350.

Katsh E and Rifkin J, Online Dispute Resolution: Resolving Conflicts in Cyberspace, Jossey-Bass, 2001.

Kaufmann-Kohler G and Schultz T, Online Dispute Resolution: Challenges for Contemporary Justice, Kluwer Law International, 2004.

Kaya S, Consumer Dispute Resolution in the Digital Age: Online Dispute Resolution, Oniki levha, 2020.

Lau T and Johnson L, The Legal and Ethical Environment of Business, Saylor Foundation, 2011.

Lavi D, "Three Is Not a Crowd: Online Mediation-Arbitration in Business to Consumer Internet Disputes", 2016, 37, University of Pennsylvania Journal of International Law, p. 871-941.

Lodder A and Zeleznikow J, Enhanced Dispute Resolution Through the Use of Information Technology, Cambridge University Press, 2010.

"Ministry of Justice Strategic Plan 2015-2019" published by Republic of Turkey Ministry of Justice, Directorate for Strategy Development (2015), <http://www.judiciaryofturkey.gov.tr/pdfler/plan.pdf> Date of Access 7 April 2021.

O'Sullivan T, "Developing an Online Dispute Resolution Scheme for New Zealand Consumers Who Shop Online-Are Automated Negotiation Tools the Key To Improving Access To Justice?”, 2015, 24, International Journal of Law and Information Technology, p. 22-43.

Özmumcu S, "Dünyada ve Ülkemizde Online Uyuşmazlık Çözümleri Bağlamında Online Tahkim ve Uygulamaları”, 2020, 78 (2), İstanbul Hukuk Mecmuası, p. 431-454.

Özmumcu S, “Online Uyuşmazlık Çözümleri ve Online Arabuluculuk “Dijital Adalet Mümkün Mü?” Sistem Üzerine Bazı Değerlendirmeler”, 2020, Prof. Dr. Türkan Rado'nun Anısına Armağan, p. 365-420. 
Parliamentary Assembly of the Council of Europe, Resolution 2054 (2015), "Access to justice and the Internet: potential and challenges", Report: Doc. 13918 of 10 November 2015.

Pekcanıtez H, "Tüketici Sorunları Hakem Heyeti", 1996, İzmir Barosu Dergisi, p. 40-53.

Philippe M, "ODR Redress System for Consumer Disputes: Clarifications, UNCITRAL Works \& EU Regulation on ODR", 2014, 1, International Journal of Online Dispute Resolution, p. 57-69.

Regulation (EU) No 524/2013 of the European Parliament and of the Council of 21 May 2013 on online dispute resolution for consumer disputes and amending Regulation (EC) No 2006/2004 and Directive 2009/22/EC (hereinafter Regulation on Consumer ODR), OJ L165/1, 18 June 2013.

Republic of Turkey Ministry of Justice Statistics (2019), <https://adlisicil. adalet.gov.tr/Resimler/SayfaDokuman/1062020170359HizmeteOzel2019-bask1-ISA.pdf> Date of Access 20 March 2021.

Ross G, "The Possible Unintended Consequences of the European Directive on Alternative Dispute Resolution and the Regulation on Online Dispute Resolution”, 2014, 10, Revista Democracia Digital e Governo Electrônico, p. 206

Rule C, Online Dispute Resolution for Business, Jossey-Bass, 2002.

Rule C, "Quantifying the Economic Benefits of Effective Redress: Large E-Commerce Data Sets and the Cost-Benefit Case for Investing in Dispute Resolution", 2012, 34 (4), University of Arkansas Little Rock Law Review, p. 767-777.

Schmitz A J, "There's an "App" for That: Developing Online Dispute Resolution to Empower Economic Development", 2018, 32, Notre Dame Journal of Law, Ethics and Public Policy, p. 1-45.

The Commission to the European Parliament, the Council and The European Economic and Social Committee on the application of Directive 2013/11/ EU of the European Parliament and of the Council on alternative dispute resolution for consumer disputes and Regulation (EU) No 524/2013 of the European Parliament and of the Council on online dispute resolution for consumer disputes, <https://eur-lex.europa.eu/legal-content/EN/ TXT/PDF/?uri=CELEX:52019DC0425\&from $=\mathrm{EN}>$ Date of Access 5 
April 2021.

The Council of Europe European Committee on Legal Co-operation, "Technical Study on Online Dispute Resolution Mechanisms", CDCJ, 2018.

The Project on the Development of Mediation in Civil Disputes (2017), $<$ https://rm.coe.int/mediation/168075fa4c $>$ Date of Access 5 April 2021.

Tutumlu M A, Tüketici Sorunları Hakem Heyetlerinin Yapısı, İşleyişi, Sorunları ve Çözüm Önerileri, Seçkin, 2006.

Uluç İ, Online Uyuşmazlık Çözümü, 2015, Prof. Dr. Ramazan Arslan'a Armağan, p. 1609-1643.

United Nations Commission on International Trade Law, 49th session, 'Report of Working Group III (Online Dispute Resolution) on the work of its thirty-third session', A/CN.9/868, 27 June-15 July 2016.

United Nations Commission on International Trade Law, 44th session, 'Report of Working Group III (Online Dispute Resolution) on the work of its twenty-second session', A/CN.9/716 ,27 June-15 July 2011.

United Nations Commission on International Trade Law, 30th session, "Online dispute resolution for cross-border electronic commerce transactions: draft procedural rules (Track II)" A/CN.9/WG.III/WP.130, 20-24 October 2014.

Yeşilova B, "6502 sayılı Yeni Tüketicinin Korunması Hakkında Kanun'a Göre Tüketici Uyuşmazlıklarının Çözümü Usulü ve Yargılama Kuralları”, 2014, 9, Terazi Hukuk Dergisi, p. 107-143.

Yüksel A, "Online International Arbitration", 2007, 4 (1), Ankara Law Review, p. 83-93.

Wang F F, Online Arbitration, Informa Law from Routledge, 2017.

Wang F F, Online Dispute Resolution, Chandos, 2009.

Zheng J, Online Resolution of E-commerce Disputes: Perspectives from the European Union, the UK, and China, Springer, 2020. 